\title{
Coordination and integration in health care. The concepts for the next reform - part II
}

\author{
Przemysław Szetela
}

Department of Public Health, Dietetics and Civilisation Diseases, Faculty of Medicine, University of Information Technology and Management, Rzeszów, Poland

Addres for correspondence: Przemysław Szetela, Department of Public Health, Dietetics and Civilisation Diseases, Faculty of Medicine, University of Information Technology and Management, Sucharskiego 2, 35-225 Rzeszów, Poland, pszetela@wsiz.rzeszow.pl

\section{Abstract}

The concept of coordinated and related integrated health care is playing an increasingly important role in modern health care systems. Societies' changing health profile, particularly in developed countries, together with the growing complexity of the health care process necessitates searching for, and implementing, solutions to increase the effectiveness and efficiency of the existing systems. This is particularly necessary when there are no opportunities for a rapid and substantial increase in funding. The substance of the planned and implemented changes is the transition from episodic, fragmented, and dispersed treatment of diseases towards the provision of coordinated health care - with a varied degree of integration which would ensure that patients receive comprehensive and continuous treatment ensured by cooperation between the health care, social care and education sectors. Achieving solution to the above challenges is included in the concept of coordinated and integrated health care, some elements of which are being implemented in the Polish system of health care.

The purpose of this paper is to present the essential aspects of the philosophy of coordinated health care and the often related concept of integration in the health care system. The starting point for this consideration of the concept of coordinated health care is its origin and its development to date. The paper focusses on the attempts made to implement the concept in the Polish health care system and on the currently formulated proposals concerning this matter.

\section{Key words: integration, comprehensiveness, coordination}

Stowa kluczowe: integracja, kompleksowość, koordynacja

\section{Experiences of coordinated health care in Poland}

The Polish health system has very limited experience of implementing the concept of coordinated health care. The concept in Poland has already been "loud" on several occasions - for the first time in the early 1990s, then during the final stage of the discussion prior to the introduction of general health insurance on $1^{\text {st }}$ January, 1999 and again between 2000 and 2002, when it was decided to carry out two pilot projects. These were conducted during the last period of the operation of the system of regional health care funds in Poland. The Western Pomeranian Regional Health Care Fund and the Łódź Regional Health Care Fund decided to carry out the projects. The
Silesian and Pomeranian Health Care Funds also gained some experience in this area, but data on this subject are not available [1]. The aim of these pilot projects was to strengthen the role of family doctors as "guides" for patients in the system. The Western Pomeranian Pilot Programme and the contract system of the Lódź Regional Health Care Fund (2002) assigned the role of coordinator and guide in the system to the primary health care doctor, (implicitly - gatekeeper, in the future - fund holder). These pilot projects also required the specialists to report back to the primary health care doctors to ensure continuation of their service funding. Unfortunately the pilot programmes were abandoned very early because of the closure of the health care funds and the introduction 
of the National Health Fund. Therefore only fragmentary data were collected, which cannot form the basis for binding conclusions. Nevertheless, it can be argued that the most important conclusion resulting from the actions taken should be, that despite attempts to attribute the role of a guide to doctors in the primary health care system, it appeared that they became the guardians of the system and limited the excessive consumption of services.

Despite relatively little experience in implementing the philosophy of coordinated care, it should be realised that more has been done in this sphere in recent years than in the last few decades. It is clear that the concept of coordinated health care has been made the primary basic aim of all the planned systemic changes in the Polish health care system.

However, it should be noted that the current solutions and formulated proposals for coordinated health care relate primarily to specific disease units rather than to the system as a whole. Nonetheless, of the activities identified and discussed below, there are proposals that have a systemic dimension, changes in primary health care and hospital operations. The following coordination and integration activities have already been implemented or are in the planning stage within the Polish health care system:

1. Speedy oncology therapy ("path"), i.e. the "oncology package" from $1^{\text {st }}$ January 2015.

This programme assumes that every patient who is suspected of contracting or developing cancer needs to be diagnosed as soon as possible. Consequently, if the suspicion is confirmed, the patient should begin treatment immediately. This premise became the basis for the implementation of the "package". Rapid oncology therapy is a completely new organisational solution intended to efficiently and promptly guide the patient through the successive stages of diagnosis and treatment in case of suspected and/or existing cancer. The total time for undertaking the initial and in-depth diagnosis, including the additional week for the patient's travel between the providers with the medical records, should not exceed 9 weeks from the day the patient is added to the waiting list. A specialist doctor directs a patient diagnosed with cancer to the consultation group most appropriate for the specific type of tumour. A clinical oncologist, a radiotherapist, a surgeon and a radiologist, possibly a psychologist, a nurse or other medical practitioner may participate in the consultation group. The group decides on the method and treatment schedule and decides on a supervisor, the coordinator. This coordinator effectively accompanies the patient to the end of treatment. The coordinator is responsible for information, administrative and organisational support, including the communications between the patient and the therapeutic team. The time for meeting the consultation group and starting treatment should not be more 2 weeks from the patient's date of admission to hospital. The patient receives comprehensive hospital treatment, which means that the hospital must ensure that all the necessary services are delivered to the patient, including those in cooperation with other providers. At the end of treatment, the coordinator will refer the patient with all documentation and recommendations to the care of a specialist. If the test results show no deterioration in health, the patient with a long-term care programme is referred to a primary care doctor, who again becomes the leading health care provider [2]. The oncology package provides total medical care to the patient from the initial diagnostic examinations in the primary health care system, through in-depth diagnostics by a specialist, hospitalisation and to the return to the GP for post-treatment follow-up examinations. The coordinator is responsible for the punctuality and quality of all medical services at each stage of the treatment.

\section{Coordinated care programme for pregnant} women (in Polish KOC) from 1 ${ }^{\text {st }}$ July 2016.

This is a comprehensive system of medical care for a mother during the pregnancy, childbirth and postpartum, post-natal, period and for her new-born baby. The programme ensures full availability of services to meet the medical recommendations. The regulation issued by the President of National Health Fund, No. 22/2016/ DSOZ dated 13 April 2016, states that pregnant women who apply for the programme must receive full-profile care within the framework of care provided by the National Health Fund. A team, composed of a gynaecologist, midwife and hospital doctors, are responsible for the security of a mother and child. Within a system of coordinated care, the team provides all maternal and child care from the moment the pregnancy is confirmed, or the patient's arrival in hospital, until the child is six weeks old. The childbirth care includes the visits of a midwife to the mother's home and counselling on breastfeeding. The pregnancy coordinator may be an obstetrician - gynaecologist or a midwife depending on the preference of the mother. The hospital - co-coordinator of the programme can obtain enhanced funding by ensuring the quality, continuity and comprehensiveness of care.

The first data received from the implementation of this care programme are very positive. It appears that in the first three months of the programme, July-September 2016, implemented in 13 hospitals, postnatal hospitalisation was reduced from 4.57 days to 3.9 days and the hospital stay of new-born children from 4.20 days to 3.57 days. Compared to the same period of the previous year, the proportion of delivery by caesarean sections decreased from $39.48 \%$ to $36.55 \%$ [3].

\section{Coordinated care programme for pregnant} women on the II or III level of perinatal care (in Polish: KOC II / III) from $1^{\text {st }}$ January 2017.

The Act of 4 November 2016 on the support of pregnant women and families "For life", has required the National Health Fund (in Polish: NFZ) to implement coordinated care for pregnant women at the II level (care for middle degree pathology) or at the III level (the most difficult pathological cases) of perinatal care. When diagnosed with developmental defects or severe disease in the foetus, a woman may receive coordinated care in the centres for the II or III reference level, i.e. in health care units that are best suited for the care of a woman and child 
in the event of a pathological pregnancy. It is assumed that pregnant women are able to have full access to services in accordance with medical recommendations, taking into account the standards of medical care needed for complicated pregnancy. There is an emphasis is on the requirement of psychological help for this group of patients [4].

\section{Child coordinated care (in Polish: DOK) from} $1^{\text {st }}$ January 2017.

The introduction of the Act "For life", has required the National Health Fund to implement coordinated child care as a separately contracted health care service. This service allocates funding to integrated neonatal care, multi-specialty paediatric care - in accordance with individual recommendations, and rehabilitation programmes for children. This programme is for children up to 3 years of age who have been diagnosed with severe and irreversible impairment or an incurable life-threatening illness that has developed during the prenatal period of child development or during labour. This service is also available for prematurely born children from pregnancies lasting less than 33 weeks, children classified as being of VLBW (very low birth weight). Care is provided in different organisational units in line with the implementation plan for the programme as developed by the coordinating body, which manages and supervises all activities. The DOK coordinator is a neonatal clinic in the organisational structure of a hospital with a neonatal unit of at least the III reference level [5].

5. Coordinated care programme for people after myocardial infarction which is planned to be implemented in 2017.

The project of comprehensive cardiac care for patients following a myocardial infarction will include: (1) intervention cardiology; (2) comprehensive rehabilitation and education; (3) electrotherapy and (4) specialist cardiac care including consultations with a cardiologist. Thus, the four modules of health care are coordinated for such patients. According to the project, the first cardiac consultation should take place no later than 6 weeks following the patient's discharge from the hospital. The number of consultations and their frequency should depend on the clinical condition of the patient, an average of four cardiac consultations have been accepted. The monitoring and evaluation of a comprehensive cardiac care programme for patients after myocardial infarction is to include both the care quality indicators and those referring to the centre delivering the comprehensive care programme. The monitoring centre will be required, after 12 months, to report on a number of the monitoring indicators, such as the percentage of patients who completed rehabilitation and any reasons for a patient's resignation from cardiac rehabilitation, the proportion of cigarette smokers, lowdensity lipoprotein (LDL) concentration and results of the measurements of blood pressure. The hospital centres providing comprehensive care in this field are to provide treatment for patients for 12 months commencing with the hospitalisation, rehabilitation and specialist visits after the hospital discharge. In return for the treatment hospitals will receive $20 \%$ greater funding than if the services of hospitalisation, visits to specialists and rehabilitation were paid individually. In addition, the National Health Fund proposes to reward the return of the patients to work. An additional of $20 \%$ of the funds is intended to be paid if the patient returns to employment within three months of being discharged from hospital [6].

\section{Coordinated care programme for children with} autism planned for implementation in 2017).

This programme is designed to cover comprehensive care during the child's development and in the mature life of a person affected by autism. It is intended to provide care for the entire life span of a person affected by autism, from a postnatal diagnosis of autism, throughout childhood and adulthood. In this case, coordinated care does not classify a person with the autism as under or over age 18 years of age and does not separate the care into paediatric care or that intended only for adults. The basic assumption is to have a smooth transition throughout life. The legal basis of the programme is the Decision of the President of the National Health Fund and the Act of $4^{\text {th }}$ November 2016 on the support for pregnant women and their families "For life".

\section{Programme for comprehensive treatment and} diagnosis of obesity planned to be implemented in 2017.

The programme aims to improve access to diagnostic tests for obesity, to implement appropriate dietary treatment, to promote healthy eating habits and provide physiotherapy and bariatric treatment. The programme is to be implemented by the system of primary health care. However, no project has yet been published.

\section{8. "Hip replacement - comprehensive care"} planned to be included as a service in the guaranteed provision package in 2017.

The planned model of comprehensive care for hip joint problems consists of three stages: (1) pre-operative care including pre-operative education and rehabilitation; (2) period of hospitalisation; (3) post-hospital care consisting of: three control visits and rehabilitation. The coordinator is responsible for the whole therapeutic process. The introduction of coordinated care for patients entitled to hip replacement should have the effect of: reducing the period of hospitalisation, early walking and reducing the number of repeat hospital stays. In addition, according to scientific evidence, the introduction of coordinated care will improve and standardise care and will increase productivity, with savings stemming primarily from the reduced period of hospitalisation. The economic analysis indicates that the integrated path for the patient is cost effective. Additionally, the shorter hospitalisation time should enable more patients to be treated each year [7]. The implementation of coordinated care in this area will allow for the patient to return to physical activity much sooner resulting in reduced social costs as there will be fewer benefits payments to be made by the social security system [7]. The implementation of these solutions should be regarded as relatively urgent consider- 
ing the long waiting time for treatment. According to the National Health Fund (March 2016), the average waiting time for hip replacement for stable patients was 581.4 days, while for urgent patients it was 189 days [7].

9. Coordinated care in primary health care (in Polish: POZ) partially implemented from $1^{\text {st }}$ July 2017 and from $1^{\text {st January } 2019 .}$

Primarily the planned changes will increase the role of primary health care. They will ensure coordination of activities with other parts of the health system, increase the role of disease prevention and health education, enable a comprehensive and holistic primary health care system focused on the patient and the local community to be implemented and increase the role of medical staff in primary health care [8]. Coordinated care in primary health care should significantly strengthen the role of providers at this level of the health system. The care will be coordinated by a closely collaborating professional team: a doctor, a nurse, a midwife, a school nurse and optionally a dietician. The competencies of the team members will be complementary, but the leading role will be given to a primary health care doctor. It has been assumed that the patient's coordinator in the whole health care system is a primary health care doctor. As the patient's guide in the health care system, the coordinator's primary task, in collaboration with a primary health care nurse and midwife where necessary, is to provide the patient with continuity and comprehensive care. To achieve this, the organisational and financial strengthening of the position of family doctors is presumed, so that they are able to effectively treat a larger proportion of their patients, rather than unnecessarily referring them to specialists or hospitals. It is expected that about $20 \%$ of public funds for health care will eventually be allocated to primary health care. As a general rule, family doctors will have the tools to diagnose and treat about $80 \%$ of their patients. The method by which the providers of primary health care are funded is intended to motivate them to provide effective, efficient and comprehensive care, coordinated care, for the patient. The capitation rate is to be modified by a motivation allowance for disease prevention and health promotion and an allowance for the care of chronically ill patients. For some disease treatment for results, performance pay, is assumed. It is also assumed that the capitation rate will be supplemented by a budget entrusted to diagnostic tests and certain elements of outpatient specialist care (in Polish: AOS). The contract for delivering health care services assumes assignment of the funding for integrated care (the budget entrusted), funds for the provision of preventive care and health education and funds for care for the chronically ill and delivered by the primary health care team (additional task funding) [8]. At the same time, it is planned to isolate the integrated care provided by a primary health care doctor to patients with selected chronic diseases funded under the entrusted budget. This care model will target patients with selected chronic diseases and will be preceded by a one-year pilot programme running from $1^{\text {st }}$ January 2018 to $31^{\text {st }}$ December 2018. The decision on the list of chronic diseases and the way in which integrated care is organised is yet to be established [8]. It is also assumed that healthcare providers will be required to monitor the quality of their primary care services, including access to services and the management and organisation of their provision, which is part of the concept of pro-quality approach to health care provision [8].

10. "Hospital network" planned to be implemented from $1^{\text {st }}$ October 2017.

On the basis of an amendment to the Act of $27^{\text {th }} \mathrm{Au}-$ gust 2004 on health care services financed from public funds, a "network of hospitals", which means the system of primary hospital security of health care services (in Polish: PSZ) will be established. It is assumed that the system will also cover outpatient specialist care services provided in outpatient clinics and night and holiday health care services [9]. Only hospitals in the network will be guaranteed a contract with the payer on a lump sum basis, the amount of which will depend on the number of patients treated in the previous year. The main purpose of the amendment is to secure patients' access to hospital treatment and outpatient specialist care (in Polish: AOS) in hospital clinics, and to ensure the continuity and comprehensiveness of the services provided. The payer wants to ensure the coordination of hospital and outpatient services. $37 \%$ of the outpatient specialist care funding will be transferred to hospitals and, thereby they can provide coordinated care. The role of a hospital network is to ensure that the patient's care is coordinated. The hospitals that qualify for the network will be required to provide patients with continued treatment, for instance by providing outpatient specialist care after discharge from hospital. Funding for the coordination of care will be included in the hospital's budget. The flat rate, which the hospital will receive, will include the funding needed for hospitalisation, for post-hospital care in specialised hospital clinics and, if necessary, for rehabilitation. Coordination is one of the main objectives of the draft law. In justifying the Act, the legislator explicitly states that one of the basic assumptions is the need to introduce mechanisms to stimulate the integration and coordination of hospital services and specialist services provided in an outpatient setting [9]. In the promised changes to the way health care providers are financed, important elements of coordination can be found. Hospitals will be "budgeted" - instead of hitherto funded for individual hospitalisations and procedures. They will receive a flat rate for the treatment of patients in specified ranges. In this statement one can find the key to promote coordination, by viewing the patient holistically. The flat rate means that finance is provided in advance, without accounting for the costs of individual procedures, but also without subsidies in the case of increasing costs. Furthermore, it is assumed that the payer may increase the flat rate if the provider agrees to supply coordinated care.

11. "Criteria directive" - the Directive of the Minister of Health of $5^{\text {th }}$ August 2016 on detailed criteria for the selection of offers in the proceedings concerning the conclusion of health care provision contracts [10]. 
The legislator intends to financially reward providers who supply coordinated care. However, until recently the criteria for evaluating offers, submitted by providers seeking public finance, did not include credit being given for providing coordinated care. Valuable points for contracting with the payer could be obtained for the comprehensiveness, price, quality, availability, cooperation with the Agency for Assessment of Medical Technologies and Tariffs (in Polish: AOTMiT), conducting electronic medical records and specialist training of doctors. However, coordination has never been included. Nevertheless, it should be realised that rewarding the providers of comprehensive services is undoubtedly a part of the broad concept of coordinated healthcare, although it is not fully implemented. Thus, the payer's allocation for coordinated health care can be traced to the criterion of comprehensiveness, although, expressis verbis, coordination is not mentioned in the directive and the accompanying appendices. Nevertheless, some steps have been taken to ensure coordinated health care in this area. On the $5^{\text {th }}$ August 2016, a criteria directive was published, which favours, in the competition for public finds, providers that will deliver comprehensive health care services. The directive gives an advantage to the providers that will deliver the most comprehensive treatment. According to the legislation, this model of care will better protect the needs of patients. Therefore, the "criteria" directive will ensure the widest packages of service - irrespective of the size of the provider regardless of whether it is private or public [11].

12. "Preparation, testing and implementation of the organisation of coordinated care (in Polish: OOK) in the health care system - Stage I the development of integrated/coordinated health care models for Poland".

The project is stage I of a long-term process of implementing the organisation of coordinated care (in Polish: OOK) in Poland and is co-financed by the European Union. Based on the agreement concluded between the Ministry of Health and the National Health Fund on $23^{\text {rd }}$ October 2015, the National Health Fund (NFZ) is responsible for its implementation. The next step in the implementation of changes in the health system will be introduced in selected locations in 2017-2021 as a stage II pilot programme and stage III will be its implementation throughout the country in 2019-2023. The aim is to improve the quality and effectiveness of health care by introducing organisational and medical standards, together with a funding model that will lead to the coordination of the various stages of diagnosis, therapy and rehabilitation. The following models are being considered: (1) a primary care model based on „fund holding” - predicting the extension of the existing competencies of a primary care doctor enabling rapid consultations with other outpatient care specialists. This will be on the basis of funds transferred to the primary care caregiver, while imposing the obligation to care for the therapeutic effects throughout the patient's consultation and treatment process; (2) the outpatient specialist care model (in
Polish: AOS) (Coordinated Outpatient Health Care) - the far-reaching integration of primary health care and outpatient specialist care, based on defined medical and organisational standards for the management of patients with chronic diseases at various stages of disease progression; the SZP model (Comprehensive Health Care - in Polish: KOZ) - covering outpatient, hospital and home care [12].

In conclusion, for the solutions, either already implemented or planned, there are incentives, mainly financial, for providers to offer coordinated care. This is intended to move from a fragmented system to one providing continuity and comprehensive health care (Table I).

\section{Summary and Conclusions}

The philosophy of coordinated and the related integrated health care originated in the United States in the 1930s and subsequently the concepts have been undergoing constant development. The effectiveness has been proved in various health systems worldwide, with international success being achieved in Great Britain, Germany, Spain, Switzerland, Hungary, Australia and several South East Asian countries. Currently, further developments are taking place in many countries within the broad concept of coordinated health care, involving various degrees of integration. Increasingly, decisions are taken to launch long-term and complex implementation of the idea of coordinated health care in selected parts, or in the entire health system.

Coordinated care can be integrated in a variety of ranges and forms. Integration mainly involves the combination of the role of the provider and the insurer, which are the "second" and "third" parties in the health system. However, integration in health care has many dimensions. In the USA, it is most common to integrate the provision and financing of health care, while in Europe - it is only the provision of health care. Integration in health care can have a variety of "widths" and "depths". The mere presence of integration, or its absence, does not prejudge the existence of coordination in the health care system. Integration is only one of the characteristics of the philosophy of coordinated care. Nonetheless, integration supports the philosophy of coordination by facilitating the achievement of the set goals. Integration can be considered from a process or structural perspective. The first approach is closer to coordination, while the second is to integration. In addition, referring to the continuum of inter-organisational arrangements in the health care sector, coordination can be seen as an indirect solution prior to full integration. Both concepts should be seen as systemic solutions, a postulated paradigm for organising and delivering health care, which recognises the primacy of a holistic view of the patient. Nevertheless, these concepts should be clearly distinguished. Coordination means primarily orderly harmonised interaction between different entities and issues, which are often autonomous and non-health related, which are important for achieving more beneficial effects or limiting various costs and losses. However, in the concept of integration in health care, it is necessary that the intentional process of com- 


\begin{tabular}{|c|c|c|}
\hline & Example & Implementation deadline \\
\hline 1 & Rapid oncology treatment, which is "Oncology package" & From $1^{\text {st }}$ January 2015 \\
\hline 2 & Coordinated care programme for pregnant women (in Polish: KOC) & 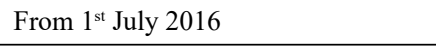 \\
\hline 3 & $\begin{array}{l}\text { Coordinated care programme for pregnant women in the second or third level of perinatal } \\
\text { care (in Polish: KOC II/III) }\end{array}$ & From $1^{\text {st }}$ January 2017 \\
\hline 4 & Child coordinated care (in Polish: DOK) & 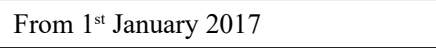 \\
\hline 5 & Coordinated care programme for people after myocardial infarction & 2017 \\
\hline 6 & Coordinated care programme for children with autism & 2017 \\
\hline 7 & Programme of comprehensive treatment and diagnosis of obesity & 2017 \\
\hline 8 & "Hip replacement - complete care" & 2017 \\
\hline 9 & Coordinated care in primary health care & $\begin{array}{l}\text { Partly from } 1^{\text {st }} \text { July } 2017 \text { and from } 1^{\text {st }} \\
\text { January } 2019\end{array}$ \\
\hline 10 & "Hospital network" & From $1^{\text {st }}$ October 2017 \\
\hline 11 & "Criteria directive" & From $1^{\text {st }}$ September 2016 \\
\hline 12 & $\begin{array}{l}\text { "Preparation, testing and implementation of the organization of coordinated care in the } \\
\text { health care system - Stage I development of integrated/coordinated health care models for } \\
\text { Poland" }\end{array}$ & From 2017 to 2023 \\
\hline
\end{tabular}

Table I. Examples of coordinated care in the Polish health system.

Source: Own study, June 2017.

bining many and different elements of the system into a single entity can be identified.

The coordinated care concept simultaneously implements a number of tasks and functions, primarily for achieving better allocation of limited resources and enhanced clinical effectiveness. It has a positive impact on the various stakeholders, the patients, the providers, the payers and the whole health care system. Today, the concept of coordination and integration in health care is seen as the response to problems in the health care system resulting from the need to govern and manage ever more complex activities and processes. These may arise from the increasing development of narrow specialisations, the widespread fragmentation and a lack of continuity and comprehensiveness of care. Together these are considered to be some of the greatest imperfections of modern health care systems, which are further aggravated by poor coordination between the sphere of cure and the sphere of care for patients. The philosophy of coordinated and integrated health care is thus an opportunity, a means of solving these problems and contributing to the optimum use of the limited resources available to the healthcare system, especially in those countries where rapid and significant increases cannot be expected.

The implementation of coordinated care in each country should always be seen as a long-term and complex development process, not a revolutionary change. The appointment of a care coordinator for the patient should be considered as a major objective in implementing the philosophy of coordinated care. This is the main difference between traditional medical practice and coordinated care. In the system of coordinated care, the transactions/interactions and relationships between the doctor and the patient, the "first" and "second" parties in the system, are monitored and controlled by the coordinator.
Coordinated health care uses a wide range of stimuli, involving incentives and restrictions, which affect all "actors" in the health system. The application of a single mechanism, typical for the concept of coordinated health care, does not imply the implementation of this concept in the health care system. However, some of the characteristic instruments are also used where a philosophy of non-coordinated health care is used. Nevertheless, their simultaneous occurrence in a coherent and well thought out manner is commonly associated with the concept. It is the overall management that is considered to be the primary determinant of coordinated care. It is difficult to assess the impact of individual instruments (institutions) used in the concept of coordinated health care. The effectiveness of the philosophy of coordinated health care is revealed only after the application of the whole management system, rather than the individual techniques, which are not subordinate to the whole vision. Which of them applies to a given organisation, the medical field or the whole system, always depends on current possibilities and needs. Although strategies for coordinating and integrating health care can vary from country to country, and the EU does not provide guidelines, the Member States are free to shape their own health care systems. However, the reform process is similar. The implementation of the coordinated care concept entails the need for: (1) changes in the way medical organisations are structured; (2) changes in the way health care is financed; (3) motivating the patient to become more involved and actively participate in all stages of medical care and (4) launching quality assessment mechanisms [13-15]. It is also important indicate the role that computerisation plays in the health care system, which is a key element for achieving the objectives required to implement the concept. 
In conclusion, the concept of coordinated health care and the frequently accompanying integration should be considered as the appropriate direction for achieving changes in modern health systems. Coordination of the patient's treatment process is one of the most effective and efficient means of meeting the growing health needs of modern societies. Correct implementation of the concept of coordinated health care, undoubtedly, enhances the entire health care system, by increasing its effectiveness, quality and efficiency. However, any threat that is associated with this concept can be fully or significantly eliminated by the use of protective measures or additional institutions. The greatest beneficiary of coordinated care is the patient, who is perceived as a whole person, in an holistic approach to health care, by considering the medical, social and psychological needs in a linked and comprehensive manner.

It must be stated that in most countries the concept of coordination in health care has been recognised as one of the main priorities for their health policy. Coordination of patient care has become the guiding theme of almost all planned changes and is currently being developed in the Polish healthcare system. Today, the added value of applying the philosophy of coordinated health care is currently appreciated by all health care entities - the patients, the providers and funding authorities. The need to implement the philosophy of coordinated health care is not controversial and is the universally accepted direction of change for modern health care systems.

\section{References}

1. Kowalska K., Kalbarczyk W.P., Koordynowana opieka zdrowotna. Doświadczenia międzynarodowe, propozycje dla Polski, Sprawne Państwo Program EY, Warszawa 2013.

2. NFZ - Narodowy Fundusz Zdrowia 2017; http://www. nfz-szczecin.pl/gposf_szybka_terapia_onkologiczna.htm (accessed: 31.03.2017).

3. NFZ - Narodowy Fundusz Zdrowia 2017; http://nfz.gov.pl/ dla-swiadczeniodawcy/koordynowana-opieka-nad-kobieta-w-ciazy-koc/publikacje-prasowe/ (accessed: 31.03.2017).

4. Zarządzenie Nr 125/2016/DSOZ Prezesa Narodowego Funduszu Zdrowia z dnia 22 grudnia 2016 r. w sprawie określenia warunków zawierania i realizacji umów o udzielanie świadczeń opieki zdrowotnej przez podmioty realizujące świadczenia koordynowanej opieki nad kobietą i dzieckiem oraz zmiany niektórych zarządzeń Prezesa Narodowego Funduszu Zdrowia w związku z przepisami ustawy o wsparciu kobiet w ciąży i rodzin „Za życiem”.

5. NFZ - Narodowy Fundusz Zdrowia 2016; http://www. nfz.gov.pl/zarzadzenia-prezesa/zarzadzenia-prezesanfz/zarzadzenie-nr-1252016dsoz,6547.html (accessed: 31.03.2017).

6. AOTMiT - Agencja Oceny Technologii Medycznych i Taryfikacji, Opieka kompleksowa po zawale mięśnia sercowego. Raport, Warszawa 2016.

7. AOTMiT - Agencja Oceny Technologii Medycznych i Taryfikacji, Rekomendacja nr 47/2016 z dnia 29 lipca 2016 r. Prezesa Agencji Oceny Technologii Medycznych i Taryfikacji w sprawie zasadności kwalifikacji świadczenia opieki zdrowotnej "Endoprotezoplastyka stawu biodrowego - opieka kompleksowa” jako świadczenia gwarantowanego, Warszawa 2016.

8. Projekt $z$ dnia 30.12.2016 roku ustawy o podstawowej opiece zdrowotnej, Warszawa 2016.

9. Projekt $\mathrm{z}$ dnia 26.09.2016 roku o zmianie ustawy o świadczeniach opieki zdrowotnej finansowanych ze środków publicznych, Warszawa 2016.

10. Rozporządzenie Ministra Zdrowia z dnia 5 sierpnia 2016 roku w sprawie szczegółowych kryteriów wyboru ofert $\mathrm{w}$ postępowaniu w sprawie zawarcia umów o udzielanie świadczeń opieki zdrowotnej.

11. MZ - Ministerstwo Zdrowia 2016; http://www.mz.gov.pl/ aktualnosci/dobry-rok-w-ministerstwie-zdrowia/ (accessed: 31.03.2017).

12. MZ - Ministerstwo Zdrowia 2017; http://www.mz.gov.pl/ aktualnosci/reformujemy-system-zeby-zmniejszyc-kolejki/ (accessed: 31.03.2017).

13. Zapaśnik A., Skłucki J., Tumasz J., Szynkiewicz P., Jędrzejczyk T., Popowski P., Koncepcja Koordynowanej Ambulatoryjnej Opieki Zdrowotnej, Polskie Towarzystwo Programów Zdrowotnych, Gdańsk 2016.

14. Hermanowski T., Rutkowski J., Zintegrowana opieka zdrowotna. Zarys problematyki, "Zeszyty Naukowe Politechniki Śląskiej. Organizacja i Zarządzanie” 2015; 83: 225-233.

15. Jończyk J., Ocena satysfakcji pacjenta w kontekście jakości opieki zdrowotnej, "Prace Naukowe Uniwersytetu Ekonomicznego we Wrocławiu" 2011; 15: 301-310.

Praca finansowana ze środków statutowych: „Integracja usług zdrowotnych, opiekuńczych i socjalnych w systemie ochrony zdrowia w ramach środków statutowych prof. Stanisławy Golinowskiej”. 